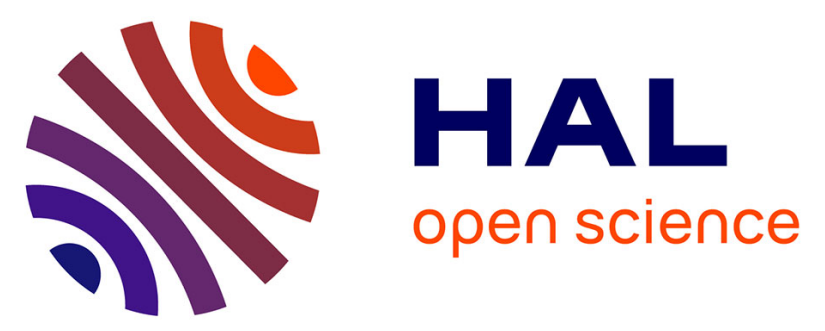

\title{
Impact of the lockdown on the burden of COVID-19 in outpatient care in France, spring 2020
}

Cécile Souty, Caroline Guerrisi, Shirley Masse, Bruno Lina, Sylvie van Der

Werf, Sibylle Bernard-Stoecklin, Clément Turbelin, Alessandra Falchi, Thomas Hanslik, Thierry Blanchon

\section{To cite this version:}

Cécile Souty, Caroline Guerrisi, Shirley Masse, Bruno Lina, Sylvie van Der Werf, et al.. Impact of the lockdown on the burden of COVID-19 in outpatient care in France, spring 2020. Infectious diseases (London, England), 2021, 53 (5), pp.376-381. 10.1080/23744235.2021.1880024 • hal-03236512

\section{HAL Id: hal-03236512 https://hal.sorbonne-universite.fr/hal-03236512}

Submitted on 26 May 2021

HAL is a multi-disciplinary open access archive for the deposit and dissemination of scientific research documents, whether they are published or not. The documents may come from teaching and research institutions in France or abroad, or from public or private research centers.
L'archive ouverte pluridisciplinaire HAL, est destinée au dépôt et à la diffusion de documents scientifiques de niveau recherche, publiés ou non, émanant des établissements d'enseignement et de recherche français ou étrangers, des laboratoires publics ou privés. 


\section{Brief Report}

Impact of the lockdown on the burden of COVID-19 in outpatient care in France, spring 2020

Cécile Souty ${ }^{1}$, Caroline Guerrisi ${ }^{1}$, Shirley Masse ${ }^{2}$, Bruno Lina ${ }^{3}$, Sylvie van der Werf ${ }^{4}$, Sibylle BernardStoecklin ${ }^{5}$, Clément Turbelin ${ }^{1}$, Alessandra Falchi ${ }^{2}$, Thomas Hanslik ${ }^{1,6,7}$, Thierry Blanchon $^{1}$

1. Sorbonne Université, INSERM, Institut Pierre Louis d'épidémiologie et de Santé publique (IPLESP UMRS 1136), Paris, France

2. UR 7310, Laboratoire de Virologie, Université de Corse, Corte, France

3. Laboratoire de Virologie des $\mathrm{HCL}$, Institut des Agents Infectieux, CNR des virus à transmission respiratoire (dont la grippe), Hôpital de la Croix Rousse, Lyon, France

4. National Reference Center for Respiratory Viruses, Molecular Genetics of RNA Viruses, CNRSUMR 3569, Univ de Paris, Institut Pasteur, Paris, France

5. Santé Publique France, Direction des maladies infectieuses, Saint-Maurice, France

6. Faculty of Health Sciences Simone Veil, University of Versailles Saint Quentin - University of Paris Saclay, France

7. Service de Médecine Interne, Hôpital Ambroise Paré, Assistance Publique-Hôpitaux de Paris (APHP), Boulogne Billancourt, France.

Corresponding author: Cécile Souty, cecile.souty@upmc.fr 


\begin{abstract}
Background

To limit the spread of SARS-CoV-2 several countries implemented measures to reduce the number of contacts such as national lockdown. We estimated the impact of the first lockdown on the burden of COVID-19 in the community in France.
\end{abstract}

\title{
Methods
}

Physicians participating in the French Sentinelles network reported the number of patients with acute respiratory infection (ARI) seen in consultation and performed nasopharyngeal swabs in a sample of these patients (first patient of the week). The swabs were tested by RT-PCR for the presence of SARS-CoV-2. Clinical and virological data was combined to estimate ARI incidence attributable to SARS-CoV-2 from March 17 to May 10, 2020.

\section{Results}

The incidence of ARI attributable to COVID-19 decreased after the second week of the lockdown period from $142(95 \% \mathrm{Cl}[101 ; 183])$ to $41(95 \% \mathrm{Cl}[21 ; 60])$ per 100000 population. A decrease was observed in all areas in metropolitan France. The youngest age groups ( $<15$ years old) were least affected with a cumulated incidence estimated to 14 per 100000 population during the study period.

\section{Conclusions}

The data collected in primary care suggests that the first lockdown implemented in France during spring 2020 significantly reduced the incidence of acute respiratory infections including COVID-19 in France and limited the geographic spread of SARS-CoV-2.

Running head: Burden of COVID-19 in France, spring 2020

Keywords: COVID-19; SARS-CoV-2; primary care 


\section{Introduction}

Severe acute respiratory syndrome coronavirus 2 (SARS-CoV-2) emerged in China in December 2019 and spread globally. The first case of the Coronavirus disease 2019 (COVID-19) in Europe was identified on January 24, 2020 in France [1,2]. Transmission of SARS-CoV-2 was then observed in the community, leading to a rapid increase of the number of cases including severe and fatal cases $[3,4]$.

Monitoring of COVID-19 in the community often uses the number of individuals testing positive for SARS-CoV-2 [5]. Following the rapid dissemination of the pandemic in the population and the inability to test each suspected case, illness indicators at a population-wide level have been implemented $[6,7]$. Existing surveillance systems in primary care designed for seasonal influenza surveillance are a valuable already operational resource. In France, the Sentinelles network has been adapted from influenza to COVID-19 surveillance since March 17, 2020.

To reduce spread of SARS-CoV-2, many countries implemented measures of social distancing, closure of schools and work offices, following the measures adopted in China [8]. In France, the first lockdown was implemented on March 17, 2020 for 8 weeks. By drastically reducing the number of contacts between individuals, the number of people infected was expected to decrease in order to avoid over-burdening of critical care [9]. However, this decrease was assessed only by modeling in hospital settings $[10,11]$.

The aim of our study was to estimate the impact of the lockdown on the burden of COVID-19 in the community in France in terms of the number of new cases and geographical spread using the data collected by the French surveillance network in primary care.

\section{Materials and methods}

\section{Surveillance of COVID-19 in primary care}

Since 1984, the Sentinelles network monitors influenza in France from data collected by general practitioners (GPs) and pediatricians all over France [12]. Starting from the spread of SARS-CoV-2 in 
the community, influenza surveillance was switched to COVID-19 surveillance on March 17, 2020. Following the recommendations [7,13], COVID-19 surveillance was based on a case definition of acute respiratory infection (ARI): sudden onset of fever (or feeling of fever) and respiratory signs. Participating GPs were invited to report patients with ARI seen in both office and telehealth visits because physician practices turned to telehealth to limit contacts [14].

Along with this clinical surveillance, physicians collect nasopharyngeal swabs from the first patient of the week presenting with ARI (GPs collect an additional swab from the first patient aged 65 years and older with ARI) [15]. RT-PCR tests for detection of SARS-CoV-2 were performed by the National Reference Centre for respiratory viruses (Paris and Lyon) and the Laboratory of virology at the University of Corsica.

All epidemiological and virological data collected from the beginning of the COVID-19 surveillance (March 17, 2020) to the end of the first lockdown period (May 10, 2020) were considered in this study.

\section{Incidence estimation}

Incidence of ARI was estimated using the methodology described elsewhere for incidence of influenza-like illness (ILI) [16]. To sum up, the mean number of reported patients presenting with ARI per sentinel GP for a given week is multiplied by the total number of practicing GPs in France. Incidence rates (per 100,000 population) were estimated by dividing incidences by yearly population size (census data).

Incidence of ARI attributable to COVID-19 was estimated by combining ARI incidence and virological data: ARI incidence was multiplied by the SARS-CoV-2 positivity rate of a given week [6]. To account for differences in attack rates by age and place, estimates were stratified by age groups $(<15$ years, 15-64 years, 65 years and older) and geographical areas (5 areas: Northwest, Southwest, Southeast, Northeast and Paris area - Île-de-France). 
Geographical spread of COVID-19 over the study period was assessed using the "kriging" method applied on weekly ARI incidence estimated at departmental level (96 departments in metropolitan France) [17]. The number of nasopharyngeal swabs collected do not allow the estimation of ARI incidences attributable to COVID-19 at a fine spatial scale.

\section{Ethics approval}

The protocol was approved by the French Data Protection Agency (CNIL\#471393) and the French ethics research committee ("Comité de Protection des Personnes"). Oral consent was obtained from swabbed patients.

\section{Results}

From March 17 to May 10, 2020, 465 GPs and 45 pediatricians participated in the surveillance. The GPs reported 6752 ARI cases. A total of 575 swabs were collected. Sixty-two (10.8\%) were positive for SARS-CoV-2. The positivity rate was higher at the beginning of the study period: $15 \%(22 / 148)$ were positive for SARS-CoV-2 in week 12 and 19\% (25/129) in week 13 (Table 1).

The incidence of ARI attributable to COVID-19 increased between week 12 and week 13, from 78 per 100000 population $(95 \% \mathrm{Cl}[54 ; 102])$ to 142 per 100000 population $(95 \% \mathrm{Cl}[101 ; 183])$. After the incidence peak in week 13 , the incidence decreased by $-71 \%$ between week 13 and week 14 , and by $-90 \%$ between week 14 and week 15 . The incidence was stabile from week 15 (Figure 1, Table 1).

The lowest incidence was found in persons below 15 years of age and the middle age group had the highest incidence (Figure 1). In persons younger than 15 years, only two specimens of 114 (1.8\%) were positive for SARS-CoV-2 over the study period while $20 \%$ (18/92) of swabs collected from those aged 65 years and above were positive.

The two most afflicted areas were Paris (Ile-de-France) and the Northeast, accounting for $75 \%$ of the incidence over the study period (Figure 2). Declining incidence was observed in all the five areas over 
the period with an incidence peak in week 13, except for the Southwest area where the highest incidence was observed in week 12.

The spatial spread of ARI incidences over the period is reported using the "kriging" method (Figure 2c). Between week 12 and week 19, the six maps showed a similar spatial distribution without indication of spatial spread over time.

\section{Discussion}

The spread of SARS-CoV-2 in France and the COVID-19 morbidity and mortality led the French authorities to impose a national lockdown during the spring of 2020. We found that this lockdown significantly reduced the incidence of acute respiratory infections including COVID-19 in France and limited the geographic spread of SARS-CoV-2.

The expected impact of a lockdown is a decrease in the number on new cases due to reduction of contacts. Other studies in France and other European countries showed a decrease using data collected at hospital level $[10,11,18-20]$. No studies have reported the burden of the COVID-19 pandemic in primary care, although the majority of infected patients have mild disease and are not seen in hospitals. We observed a decrease in incidence after the second week of the lockdown. This lag of two weeks is compatible with the generation time of COVID-19 [21,22]. In addition, the decrease in COVID-19 and ARI incidences was synchronous in all five areas, as also reported at the hospital level [23]. This suggests that the lockdown had a major impact by reducing the number of new cases of COVID-19 in outpatient care. The observed decrease of global ARI incidence also suggests that lockdown strategies are effective to limit the spreading of common respiratory pathogens, as observed in other countries $[24,25]$.

The two most afflicted areas in France were Paris (Ile-de-France) and the Northeast accounting for three quarters of the ARI incidence attributable to COVID-19 over the period. This is consistent with the intense activity observed at hospital level in these regions early in 2020 [23] and the higher prevalence of SARS-CoV-2 antibodies estimated in Ile-de-France and the Northeast after the 
lockdown [26]. We also observed that clusters with high ARI incidence were spatially contained over time. These observations suggest that travel ban during the lockdown effectively limited the spread of SARS-CoV-2 from one region to another, which is consistent with results in China [9].

Our study has several limitations. We estimated the number of COVID-19 patients presenting with ARI in primary care, excluding asymptomatic patients and patients with other clinical presentations, as well as patients who did not see a GP. However, in the French crowdsourced surveillance system GrippeNet.fr, no large variations in health-seeking behavior of people presenting with ARI were reported during the study period [27]. In addition, the lockdown made the collection of nasopharyngeal swabs difficult due to increased teleconsultations and major disturbances in the postal service. Finally, we could not identify all pathogens responsible of the respiratory infections during the study period, as the swabs were not routinely tested for other respiratory viruses than SARS-CoV-2 during this period.

\section{Conclusion}

The surveillance system in primary care allowed monitoring of the spread of COVID-19 in the community and measurement of the impact of public health interventions. The first national lockdown may have contributed considerably to the decline of new cases of COVID-19 early in 2020. Public health interventions, including testing, tracing and isolation, need to be continued to keep transmission of SARS-CoV-2 under control.

Disclosure of interest: The authors report no conflict of interest

Funding: Not applicable 


\section{References}

1. Bernard Stoecklin S, Rolland P, Silue Y, Mailles A, Campese C, Simondon A, et al. First cases of coronavirus disease 2019 (COVID-19) in France: surveillance, investigations and control measures, January 2020. Euro Surveill. 2020;25(6):2000094.

2. Lescure F-X, Bouadma L, Nguyen D, Parisey M, Wicky P-H, Behillil S, et al. Clinical and virological data of the first cases of COVID-19 in Europe: a case series. Lancet Infect Dis. 2020 Mar 27; 3. Boëlle P-Y, Souty C, Launay T, Guerrisi C, Turbelin C, Behillil S, et al. Excess cases of influenzalike illnesses synchronous with coronavirus disease (COVID-19) epidemic, France, March 2020. Euro Surveill. 2020 Apr 9;25(14):2000326.

4. Grasselli G, Zangrillo A, Zanella A, Antonelli M, Cabrini L, Castelli A, et al. Baseline Characteristics and Outcomes of 1591 Patients Infected With SARS-CoV-2 Admitted to ICUs of the Lombardy Region, Italy. JAMA. 2020 06;323(16):1574-81.

5. Dong E, Du H, Gardner L. An interactive web-based dashboard to track COVID-19 in real time. Lancet Infect Dis. 2020;20(5):533-4.

6. Lipsitch M, Hayden FG, Cowling BJ, Leung GM. How to maintain surveillance for novel influenza A H1N1 when there are too many cases to count. Lancet. 2009 Oct 3;374(9696):1209-11.

7. Lipsitch M, Swerdlow DL, Finelli L. Defining the Epidemiology of Covid-19 - Studies Needed. N Engl J Med. 2020 Mar 26;382(13):1194-6.

8. Kraemer MUG, Yang C-H, Gutierrez B, Wu C-H, Klein B, Pigott DM, et al. The effect of human mobility and control measures on the COVID-19 epidemic in China. Science. 2020 Mar 25;368(6490):493-7.

9. Tian H, Liu Y, Li Y, Wu C-H, Chen B, Kraemer MUG, et al. An investigation of transmission control measures during the first 50 days of the COVID-19 epidemic in China. Science. 2020 Mar 31;368(6491):638-42.

10. Salje H, Tran Kiem C, Lefrancq N, Courtejoie N, Bosetti $P$, Paireau J, et al. Estimating the burden of SARS-CoV-2 in France. Science. 2020 May 13;369(6500):208-11.

11. Di Domenico L, Pullano G, Sabbatini CE, Boëlle P-Y, Colizza V. Impact of lockdown on COVID19 epidemic in Île-de-France and possible exit strategies. BMC Med. 2020 30;18(1):240.

12. Flahault A, Blanchon T, Dorléans $Y$, Toubiana L, Vibert JF, Valleron AJ. Virtual surveillance of communicable diseases: a 20-year experience in France. Stat Methods Med Res. 2006 Oct;15(5):41321.

13. World Health Organization. Global surveillance for COVID-19 caused by human infection with COVID-19 virus - Interim guidance 20 March 2020 [Internet]. 2020. Available from: WHO/2019nCoV/SurveillanceGuidance/2020.6

14. Mehrotra A, Ray K, Brockmeyer DM, Barnett ML, Bender JA. Rapidly Converting to "Virtual Practices": Outpatient Care in the Era of Covid-19 | Catalyst non-issue content [Internet]. [cited 2020 May 12]. Available from: https://catalyst.nejm.org/doi/full/10.1056/CAT.20.0091

15. Souty C, Masse S, Valette M, Behillil S, Bonmarin I, Pino C, et al. Baseline characteristics and clinical symptoms related to respiratory viruses identified among patients presenting with influenzalike illness in primary care. Clin Microbiol Infect. 2019 Sep;25(9):1147-53.

16. Souty C, Amoros P, Falchi A, Capai L, Bonmarin I, van der Werf S, et al. Influenza epidemics observed in primary care from 1984 to 2017 in France: A decrease in epidemic size over time. Influenza Other Respir Viruses. 2019;13(2):148-57.

17. Carrat F, Valleron AJ. Epidemiologic mapping using the 'kriging' method: application to an influenza-like illness epidemic in France. Am J Epidemiol. 1992 Jun 1;135(11):1293-300.

18. Flaxman S, Mishra S, Gandy A, Unwin HJT, Mellan TA, Coupland H, et al. Estimating the effects of non-pharmaceutical interventions on COVID-19 in Europe. Nature. 2020 Aug;584(7820):257-61.

19. Dehning J, Zierenberg J, Spitzner FP, Wibral M, Neto JP, Wilczek M, et al. Inferring change points in the spread of COVID-19 reveals the effectiveness of interventions. Science. 2020 Jul 
10;369(6500).

20. Okell LC, Verity R, Watson OJ, Mishra S, Walker P, Whittaker C, et al. Have deaths from COVID-19 in Europe plateaued due to herd immunity? The Lancet. 2020 Jun 20;395(10241):e110-1.

21. Cereda D, Tirani M, Rovida F, Demicheli V, Ajelli M, Poletti P, et al. The early phase of the COVID-19 outbreak in Lombardy, Italy. arXiv:200309320 [q-bio]. 2020 Mar 20;

22. Li Q, Guan X, Wu P, Wang X, Zhou L, Tong Y, et al. Early Transmission Dynamics in Wuhan, China, of Novel Coronavirus-Infected Pneumonia. N Engl J Med. 2020 Jan 29;382(13):1199-207.

23. Cauchemez S, Kiem CT, Paireau J, Rolland P, Fontanet A. Lockdown impact on COVID-19 epidemics in regions across metropolitan France. The Lancet. 2020 Oct 10;396(10257):1068-9.

24. Kuitunen I, Artama M, Mäkelä L, Backman K, Heiskanen-Kosma T, Renko M. Effect of Social Distancing Due to the COVID-19 Pandemic on the Incidence of Viral Respiratory Tract Infections in Children in Finland During Early 2020. Pediatr Infect Dis J. 2020 Dec;39(12):e423-7.

25. Yeoh DK, Foley DA, Minney-Smith CA, Martin AC, Mace AO, Sikazwe CT, et al. The impact of COVID-19 public health measures on detections of influenza and respiratory syncytial virus in children during the 2020 Australian winter. Clin Infect Dis [Internet]. 2020 Sep 28 [cited 2021 Jan 8]; Available from: https://www.ncbi.nlm.nih.gov/pmc/articles/PMC7543326/

26. Vu SL, Jones G, Anna F, Rose T, Richard J-B, Bernard-Stoecklin S, et al. Prevalence of SARSCoV-2 antibodies in France: results from nationwide serological surveillance. medRxiv. 2020 Oct 21;2020.10.20.20213116.

27. Pullano G, Di Domenico L, Sabbatini CE, Valdano E, Turbelin C, Debin M, et al. Underdetection of COVID-19 cases in France threatens epidemic control. Nature. 2020 Dec 21; 


\section{Table}

Table 1. Incidence of acute respiratory infection and acute respiratory infection attributable to COVID-19 with $95 \%$ confidence intervals, and positivity rates of nasopharyngeal swabs to SARS-CoV2, week 12 to week 19, 2020, France.

\begin{tabular}{|c|c|c|c|c|}
\hline Age groups & Weeks & $\begin{array}{c}\text { Percentage of } \\
\text { specimens tested } \\
\text { positive to SARS- } \\
\text { CoV-2 }\end{array}$ & $\begin{array}{c}\text { ARI incidence (per } \\
100000 \text { population) } \\
{[95 \% \mathrm{Cl}]}\end{array}$ & $\begin{array}{c}\text { ARI incidence } \\
\text { attributable to } \\
\text { COVID-19 (per } 100 \\
000 \text { population) } \\
{[95 \% \mathrm{CI}]}\end{array}$ \\
\hline \multirow[t]{8}{*}{ Overall } & Week 12 & $15 \%(22 / 148)$ & $415[394 ; 436]$ & $78[54 ; 102]$ \\
\hline & Week 13 & $19 \%(25 / 129)$ & $452[430 ; 474]$ & $142[101 ; 183]$ \\
\hline & Week 14 & $8 \%(7 / 90)$ & $325[306 ; 344]$ & $41[21 ; 60]$ \\
\hline & Week 15 & $5 \%(3 / 65)$ & $145[132 ; 158]$ & $4[1 ; 7]$ \\
\hline & Week 16 & $8 \%(3 / 40)$ & $93[83 ; 103]$ & $4[1 ; 7]$ \\
\hline & Week 17 & $8 \%(2 / 26)$ & $70[61 ; 79]$ & $6[0 ; 12]$ \\
\hline & Week 18 & $0 \%(0 / 34)$ & $53[45 ; 61]$ & $0[0 ; 5]$ \\
\hline & Week 19 & $0 \%(0 / 42)$ & $42[35 ; 49]$ & $0[0 ; 4]$ \\
\hline \multirow[t]{8}{*}{$<15$ years } & Week 12 & $0 \%(0 / 32)$ & $315[272 ; 358]$ & $0[0 ; 34]$ \\
\hline & Week 13 & $3 \%(1 / 29)$ & 203 [168;238] & $11[0 ; 30]$ \\
\hline & Week 14 & $0 \%(0 / 20)$ & $137[108 ; 166]$ & $0[0 ; 22]$ \\
\hline & Week 15 & $0 \%(0 / 11)$ & $52[33 ; 71]$ & $0[0 ; 13]$ \\
\hline & Week 16 & $7 \%(1 / 14)$ & $39[23 ; 55]$ & $3[0 ; 9]$ \\
\hline & Week 17 & $0 \%(0 / 8)$ & $32[18 ; 46]$ & $0[0 ; 10]$ \\
\hline & Week 18 & $0 \%(0 / 12)$ & $22[10 ; 34]$ & $0[0 ; 5]$ \\
\hline & Week 19 & $0 \%(0 / 18)$ & $21[9 ; 33]$ & $0[0 ; 4]$ \\
\hline \multirow[t]{8}{*}{$15-64$ years } & Week 12 & $17 \%(15 / 88)$ & $512[482 ; 542]$ & $107[70 ; 144]$ \\
\hline & Week 13 & $22 \%(16 / 74)$ & $589[558 ; 620]$ & $202[138 ; 266]$ \\
\hline & Week 14 & $10 \%(6 / 59)$ & $429[401 ; 457]$ & $49[19 ; 79]$ \\
\hline & Week 15 & $2 \%(1 / 41)$ & $182[163 ; 201]$ & $3[0 ; 7]$ \\
\hline & Week 16 & $9 \%(2 / 22)$ & $116[101 ; 131]$ & $6[1 ; 11]$ \\
\hline & Week 17 & $13 \%(2 / 16)$ & 86 [73;99] & $10[0 ; 20]$ \\
\hline & Week 18 & $0 \%(0 / 18)$ & $65[54 ; 76]$ & $0[0 ; 11]$ \\
\hline & Week 19 & $0 \%(0 / 19)$ & $50[40 ; 60]$ & $0[0 ; 8]$ \\
\hline \multirow[t]{8}{*}{$>=65$ years } & Week 12 & $25 \%(7 / 28)$ & $236[201 ; 271]$ & $66[28 ; 104]$ \\
\hline & Week 13 & $31 \%(8 / 26)$ & 287 [249;325] & $84[40 ; 127]$ \\
\hline & Week 14 & $9 \%(1 / 11)$ & $195[162 ; 228]$ & $53[13 ; 94]$ \\
\hline & Week 15 & $15 \%(2 / 13)$ & $123[96 ; 150]$ & $10[3 ; 17]$ \\
\hline & Week 16 & $0 \%(0 / 3)$ & 77 [56;98] & $0[0 ; 43]$ \\
\hline & Week 17 & $0 \%(0 / 2)$ & $59[41 ; 77]$ & $0[0 ; 39]$ \\
\hline & Week 18 & $0 \%(0 / 4)$ & $45[29 ; 61]$ & $0[0 ; 22]$ \\
\hline & Week 19 & $0 \%(0 / 5)$ & $35[21 ; 49]$ & $0[0 ; 15]$ \\
\hline
\end{tabular}




\section{Figures}

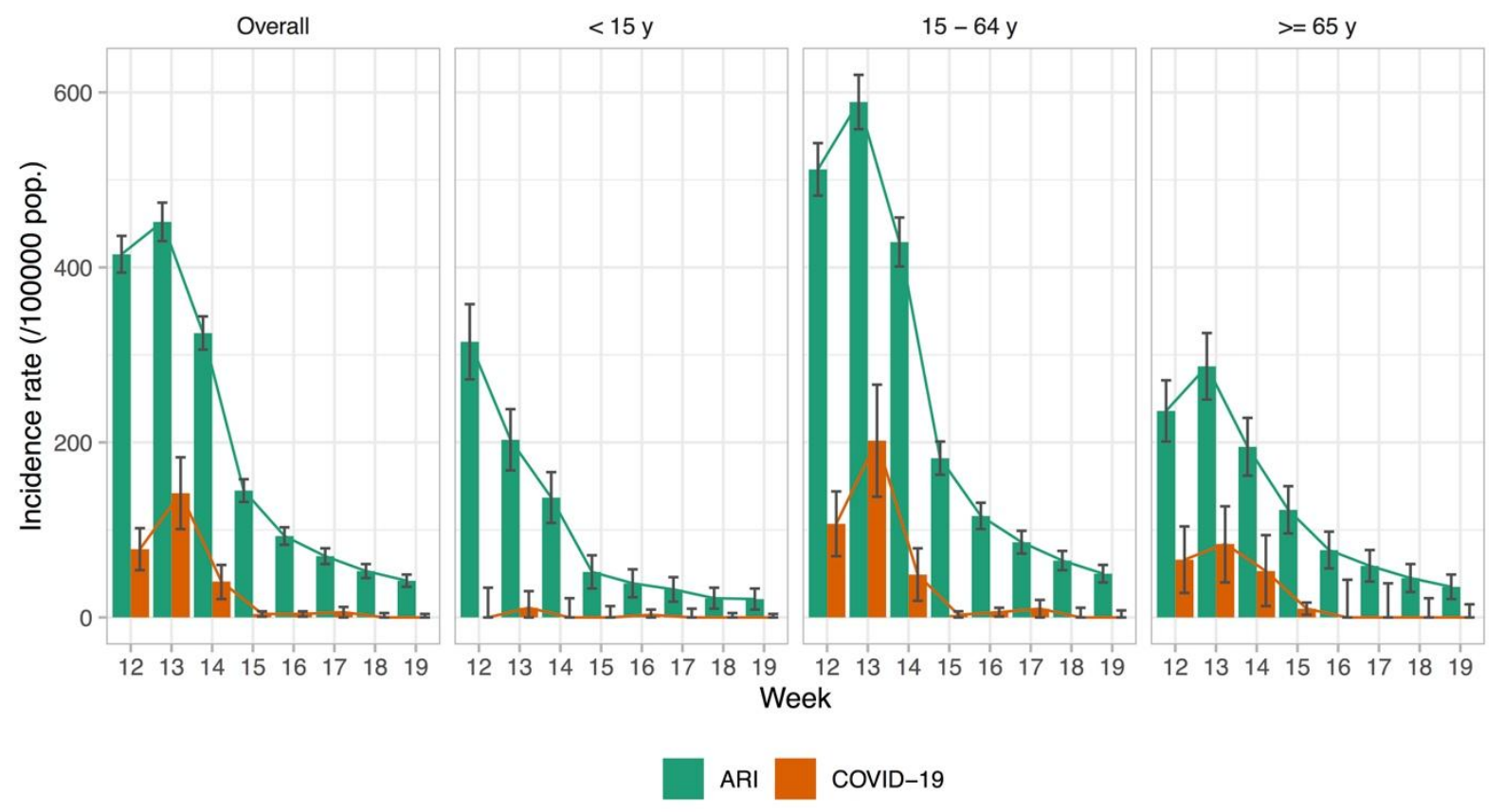

Figure 1. Incidence rate estimates (and 95\% confidence intervals) of acute respiratory infection and acute respiratory infection attributable to COVID-19 according to age groups, weeks 12 to 19,2020 , France 
a.

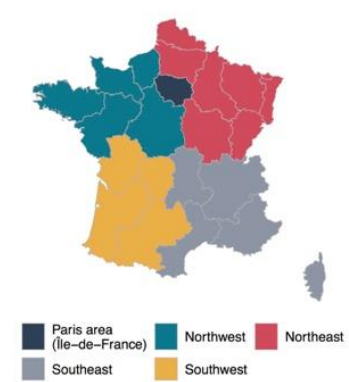

b.
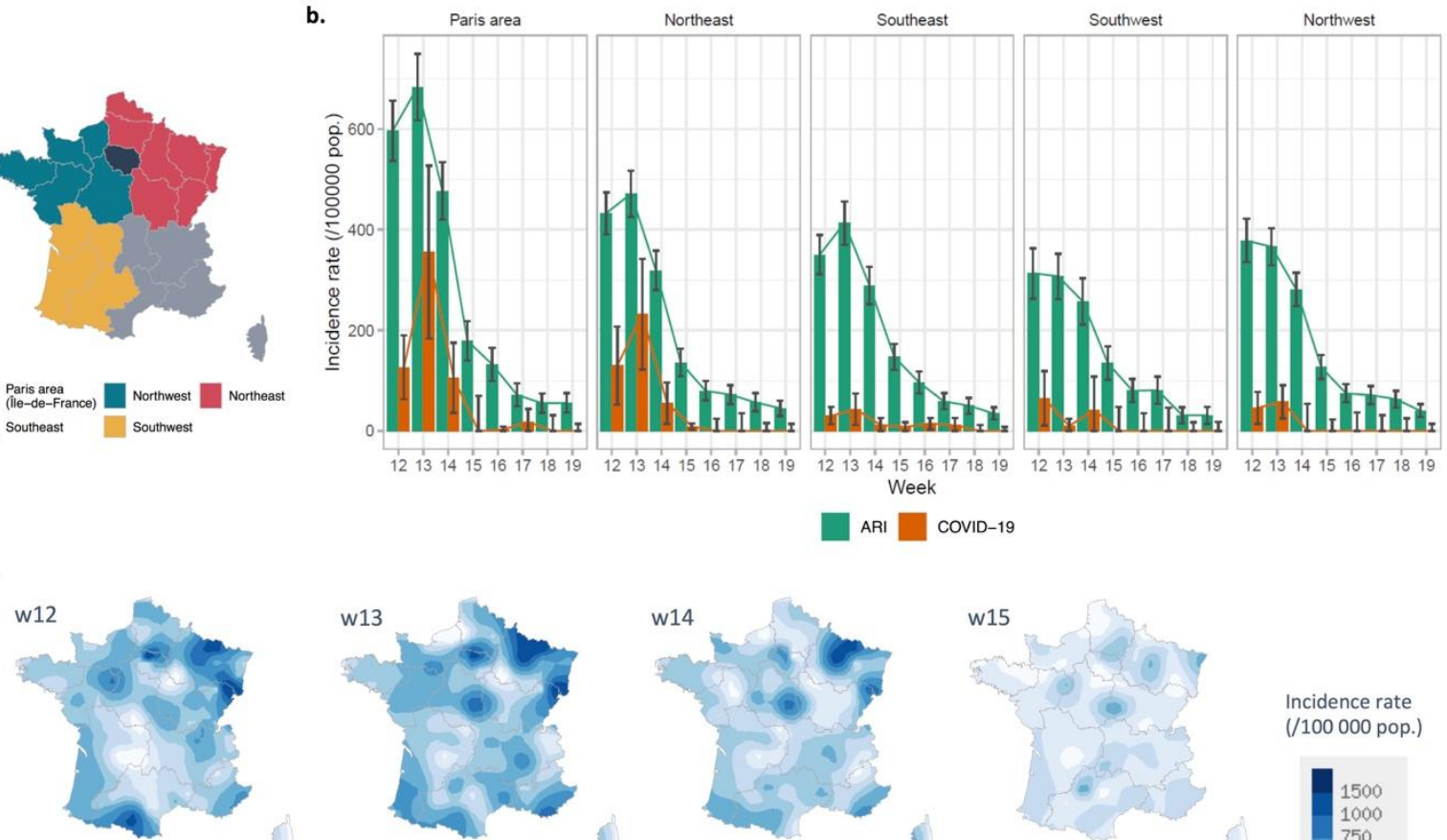

w16

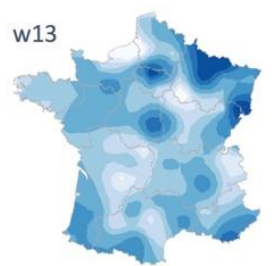

w17
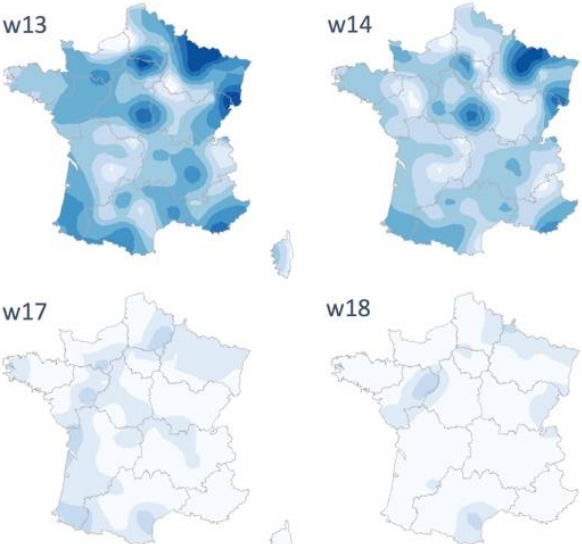

w18

w15

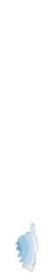

क्रा

Incidence rate (/100 000 pop.)

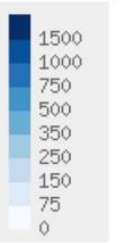

Figure 2. Incidence rates estimated by geographical areas weeks 12 to 19, 2020, France (a) Geographical distribution of the five areas in France, (b) Incidence (and 95\% confidence intervals) of acute respiratory infection and acute respiratory infection attributable to COVID-19 in five geographical areas, (c) incidence of acute respiratory infections estimated through the "kriging" method. 